\title{
Distribution Characteristics and Ecological Risk Assessment of Heavy Metals under Reclaimed Water Irrigation and Water Level Regulations in Paddy Field
}

\author{
Menghua Xiao ${ }^{1}$, Yuanyuan $\mathrm{Li}^{1,2 *}$ \\ 'Zhejiang Institute of Hydraulics and Estuary (Zhejiang Institute of Marine Planning and Design), \\ Hangzhou, 310020, P.R. China \\ ${ }^{2}$ North China University of Water Resource and Electric Power, Zhengzhou, 450045, P.R. China
}

Received: 28 August 2021

Accepted: 31 October 2021

\begin{abstract}
This article carried out research on changes of heavy metals in soil and rice plant with different reclaimed water irrigation and water level regulations. The results showed that, the heavy metals content in soil was increased after irrigated by reclaimed water, but short-term reclaimed water irrigation will not cause heavy metal pollution to the soil. The coefficient of variation had a stronger level of variation for $\mathrm{Cd}, \mathrm{Cr}$ and $\mathrm{Cu}(>30 \%)$. With $\mathrm{R} 2$ irrigation, the $\mathrm{Zn}, \mathrm{Pb}, \mathrm{Cd}, \mathrm{Cr}$ content in rice root could be reduced, and the $\mathrm{Cd}, \mathrm{Cr}$ content in rice stem could be reduced, and also the $\mathrm{Zn}, \mathrm{Cd}, \mathrm{Cr}$ content in rice leaf could be reduced. The ecological risk coefficient of $\mathrm{Cd}$ in the soil was the highest, followed by $\mathrm{Cu}$ and $\mathrm{Pb}$, and the risk coefficient of $\mathrm{Cr}$ and $\mathrm{Zn}$ was lower. The soil risk index at $60-80 \mathrm{~cm}$ soil layer was the highest under R1 irrigation, while it was the highest at $20-40 \mathrm{~cm}$ soil layer under R2. Among them, the ecological risk of $\mathrm{Cd}$ under irrigation of various water sources was the highest. R1 was at a strong risk on average, and R2 and R3 were moderate risks. Under reclaimed water irrigation, $\mathrm{Cd}, \mathrm{Pb}$, $\mathrm{Cr}$ had significant correlation to soil Ec, while $\mathrm{Cu}$ had significant correlation to $\mathrm{NO}_{3}^{-}-\mathrm{N}$, and $\mathrm{Zn}$ had a significant correlation to sanity and $\mathrm{NH}_{4}^{+}-\mathrm{N}$. Therefore, $\mathrm{R} 2$ source might be the safest and efficient irrigation source.
\end{abstract}

Keywords: heavy metals, ecological risk assessment, reclaimed water irrigation, water level regulation, paddy field

*e-mail: liya66720@126.com 


\section{Introduction}

As the main food crop in China, rice had a large planting area and consumed a lot of water. Therefore, as supplementary water for agricultural irrigation, the recycling of rural sewage was particularly necessary $[1,2]$. After sewage was treated according to a certain treatment process, it could be used for farmland irrigation, which will greatly ease the contradiction of agricultural water shortage, and also it contained nutrients which could reduce the amount of chemical fertilizer application and improve soil fertility [3-6]. However, compared with fresh water, reclaimed water still contained a certain amount of harmful substances, and it may cause pollution of soil, crops, surface and ground water when it was used for irrigation [7-10].

Guo et al. found that after reclaimed water irrigation, soil salinity and conductivity increased compared to the control treatment, while the organic matter showed no significance[11]. Xu et al. have found that soil salinity increased obviously at $40-80 \mathrm{~cm}$ soil layer after reclaimed water irrigation, while it had no significance on soil $\mathrm{pH}$ and conductivity[12]. In addition to the nutrients needed for plant growth, sewage was often accompanied by some toxic and harmful substances such as heavy metals. Irrigation of sewage will cause heavy metals and other toxic substances in the sewage to be in soils and various organs of crops, causing harm to human health[13]. Researchers have found that the soil in the sewage and the reclaimed water irrigation areas showed different levels of heavy metal accumulation, but there was no difference in the heavy metal content of wheat grains [14]. Angin [15] found that soil organic matter, soil conductivity, total nitrogen, and heavy metals increased, while $\mathrm{pH}$ value decreased with long-term sewage irrigation, and the similar results were found by Zhao [16]. Han indicated that soil salinity was greatly increased with reclaimed water irrigation or sufficient irrigation [17]. Also there were studies indicating the risk of heavy metal pollution in the soil caused by the use of wastewater after treated for irrigation in the short to medium term is very low, and did not cause heavy metals increase and will not cause pollution to the soil environment, groundwater and crops and the harmful effects on the soil are mainly concentrated in the soil layer with a soil depth of 20-40 cm, while long-term use of reclaimed water for irrigation may cause the accumulation of heavy metals in the soil, and even reach the level of serious toxic hazards [18-20].

Liu et al. showed that the soil Cd pollution risk in northeastern Sichuan was generally low, which was lower than the control value. However, there was a phenomenon that the soil content did not exceed the standard but the rice content exceeded the standard [21]. Wang et al. showed that soil cadmium in karst areas was mainly non-polluted and lightly polluted, and the effectiveness of cadmium on organisms was mainly affected by changes in soil $\mathrm{pH}$ and soil selenium content[22]. The research of Shan et al. showed that the average value of the comprehensive potential environmental risk index Ri of harmful heavy metals in the soil of the main citrus producing areas in Guangxi, Guigang and other places was 342.4, which was a strong

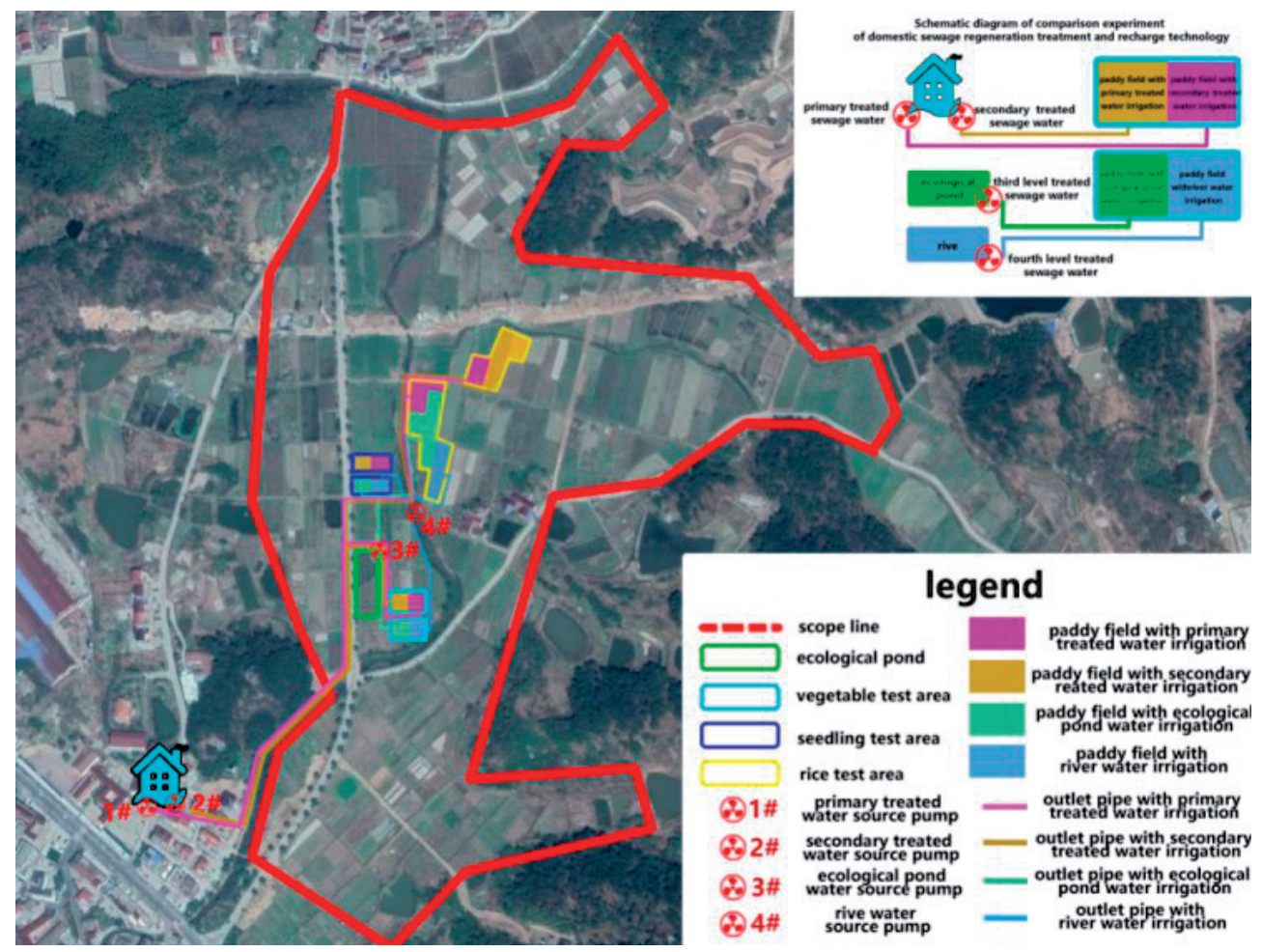

Fig. 1. Experimental site location. 
ecological risk and was mainly affected by the pollution of cadmium and mercury[23]. Dou et al. discussed the vertical distribution and migration characteristics of heavy metals in the farmland soil environment and the potential ecological risks. The comprehensive potential ecological risk index evaluation results showed that the surface soil in the study area was a moderate ecological hazard, and the middle and bottom soil was a slight ecological hazard. The ecological risk of heavy metals on the surface of farmland soil was high, which was mainly caused by cadmium pollution[24].

In this study, we did experiment on change of heavy metals both in soil and rice plant after irrigated by two different grades of reclaimed water with comparison to river water. The aim of this study was to investigate the degree of heavy metal pollution on soil and rice plant, and to evaluate the environment risk under reclaimed water irrigation, providing the guidance for utilization of rural sewage.

\section{Materials and Methods}

\section{Experimental Site}

This study was carried out at Zhousan County (N28 48', E120 $10^{\prime}$ ) in Zhejiang Province from June to October, 2020 (Fig.1). The region has a subtropical monsoon climate, with an average annual evaporation of $1787 \mathrm{~mm}$ and average annual rainfall is $930.2 \mathrm{~mm}$. The average annual sunshine is 1909 hours, and yearly average temperature is $17.7^{\circ} \mathrm{C}$. The maximum and minimum air temperatures is $39.9^{\circ} \mathrm{C}$ and $-14.5^{\circ} \mathrm{C}$, respectively, and there are 245 frost-free days per year.

The rice variety is Jiayou Zhongke 13-1, and the soil in experimental site is sand or sand clay, with bulk density of $1.3-1.5 \mathrm{~g} / \mathrm{cm}^{3}$. The transplantation date was Jun. 26, and harvested at Oct. 2. The rice density was 10 plants per $\mathrm{m}^{2}$. There were 2 fertilization during growth period, with basal fertilizer of $200 \mathrm{~kg} / \mathrm{ha}$ compound fertilizer and $100 \mathrm{~kg} / \mathrm{ha}$ urea applied on Jun. 25, and dressing was $250 \mathrm{~kg} / \mathrm{ha}$ compound fertilizer applied on Jul.12. The soil $(0-80 \mathrm{~cm})$ physical and chemical properties are shown in Table 1.

\section{Experiential Design}

There are 3 irrigation water resources, respectively primary reclaimed water(R1), secondary reclaimed water(R2) and river water(R3). The reclaimed water was from domestic sewage treatment plant, and the water quality condition during experiment was shown in Table 2. 3 water level control regimes (W1, W2, W3) are also set with different water resources (Table 3). Each treatment was replicated 3 times, therefore 27 experimental plots are set in total. Each plot was $100 \mathrm{~m}^{2}(20 \mathrm{~m} \times 5 \mathrm{~m})$ and separated by plastic impermeable film.

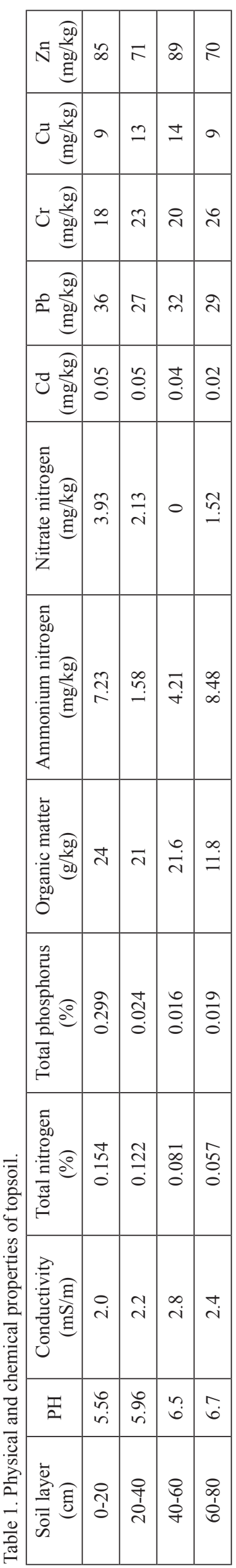


Table 2 . Water quality descriptive statistics during experimental period $(\mathrm{mg} / \mathrm{L})$.

\begin{tabular}{|c|c|c|c|c|c|c|c|}
\hline Water resource & Indicator & Max Value & Min Value & Standard Deviation & Average & Kurtosis & Skewness \\
\hline \multirow{5}{*}{$\mathrm{R} 1$} & $\mathrm{COD}$ & 84 & 15 & 26.794 & 29.5 & 5.855 & 2.410 \\
\cline { 2 - 9 } & $\mathrm{LAS}$ & 0.88 & 0.06 & 0.315 & 0.25 & 5.199 & 2.247 \\
\cline { 2 - 9 } & $\mathrm{NH}_{4}^{+}-\mathrm{N}$ & 11.9 & 8.25 & 1.645 & 9.647 & -1.782 & 0.916 \\
\cline { 2 - 9 } & $\mathrm{NO}_{3}^{-}-\mathrm{N}$ & 0.061 & 0.016 & 0.019 & 0.034 & -1.452 & 0.642 \\
\hline \multirow{5}{*}{$\mathrm{R} 2$} & $\mathrm{COD}$ & 59 & 10 & 16.783 & 24.1 & 0.719 & 1.291 \\
\cline { 2 - 9 } & $\mathrm{LAS}$ & 0.16 & 0 & 0.058 & 0.048 & -0.425 & 0.827 \\
\cline { 2 - 9 } & $\mathrm{NH}_{4}^{+}-\mathrm{N}$ & 11.9 & 3.52 & 2.837 & 7.712 & -0.946 & -0.174 \\
\cline { 2 - 9 } & $\mathrm{NO}_{3}^{-}-\mathrm{N}$ & 6.25 & 0.01 & 2.455 & 1.364 & 1.238 & 1.687 \\
\hline \multirow{5}{*}{$\mathrm{R} 3$} & $\mathrm{COD}^{*}$ & 56 & 7 & 15.712 & 23.45 & 0.710 & 1.251 \\
\cline { 2 - 9 } & $\mathrm{LAS}^{-}$ & 0.1 & 0 & 0.041 & 0.035 & -1.875 & 0.418 \\
\cline { 2 - 9 } & $\mathrm{NH}_{4}^{+}-\mathrm{N}$ & 1.49 & 0.116 & 0.394 & 0.711 & 0.143 & 0.393 \\
\cline { 2 - 9 } & $\mathrm{NO}_{3}^{-}-\mathrm{N}$ & 2.56 & 0.624 & 0.578 & 1.048 & 4.680 & 2.078 \\
\hline
\end{tabular}

Table 3. Water level control standard (mm).

\begin{tabular}{|c|c|c|c|c|c|c|c|}
\hline Treatment & $\begin{array}{l}\text { Upper and } \\
\text { lower limit }\end{array}$ & Re-greening & $\begin{array}{l}\text { Early } \\
\text { tillering }\end{array}$ & $\begin{array}{l}\text { Late } \\
\text { tillering }\end{array}$ & Jointing booting & $\begin{array}{l}\text { Heading } \\
\text { flowering }\end{array}$ & Milkying \\
\hline \multirow{3}{*}{ W1 } & Lower limit & 0 & $\begin{array}{c}\text { Field exposing } \\
3-5 \mathrm{~d} \\
\end{array}$ & $\begin{array}{c}\text { Field exposing } \\
1-2 \mathrm{~d}\end{array}$ & $\begin{array}{c}\text { Field exposing } \\
1-2 \mathrm{~d}\end{array}$ & $\begin{array}{l}\text { Field exposing } \\
1-2 d\end{array}$ & $\begin{array}{c}\text { Field exposing } \\
3-5 d\end{array}$ \\
\hline & Upper limit & 30 & 30 & Field drying & 40 & 40 & 30 \\
\hline & $\begin{array}{l}\text { Rain/sewage } \\
\text { storage limit }\end{array}$ & 50 & \multicolumn{2}{|c|}{70} & 80 & 80 & 60 \\
\hline \multirow{3}{*}{ W2 } & Lower limit & 0 & 10 & 10 & 10 & 10 & 10 \\
\hline & Upper limit & 30 & 50 & Field drying & 50 & 50 & 50 \\
\hline & $\begin{array}{l}\text { Rain/sewage } \\
\text { storage limit }\end{array}$ & 50 & \multicolumn{2}{|c|}{70} & 100 & 100 & 100 \\
\hline \multirow{3}{*}{ W3 } & Lower limit & 0 & 40 & 40 & 40 & 40 & 10 \\
\hline & Upper limit & 30 & 60 & Field drying & 60 & 60 & 60 \\
\hline & $\begin{array}{l}\text { Rain/sewage } \\
\text { storage limit }\end{array}$ & 50 & \multicolumn{2}{|c|}{100} & 150 & 150 & 100 \\
\hline
\end{tabular}

\section{Indicators and Method}

The $\mathrm{Cd}$ in soil was detected by graphite furnace atomic absorption spectrophotometry, and $\mathrm{Pb}, \mathrm{Cr}$, $\mathrm{Cu}, \mathrm{Zn}$ was detected by flame atomic absorption spectrophotometry with atomic absorption spectrometer AA900T. The $\mathrm{Cu}$ and $\mathrm{Zn}$ in rice plant was detected by flame atomic absorption spectrometry, and $\mathrm{Pb}, \mathrm{Cd}$, $\mathrm{Cr}$ was detected by inductively coupled plasma mass spectrometry.

Before the experiment, soil properties such as $\mathrm{NH}_{4}^{+}-\mathrm{N}$ and $\mathrm{NO}_{3}^{-}-\mathrm{N}$ was measured by potassium chloride solution extraction-spectrophotometry (UV-1800), and $\mathrm{pH}$ was measured by potentiometric method, with organic matter measured by potassium dichromate-sulfuric acid solution method, and conductivity was by electrode method.

As for water quality of irrigation water, COD was measured by dichromate method(KHCOD-12), $\mathrm{NH}_{4}^{+}-\mathrm{N}$ was measured by Nessler's reagent spectrophotometry, $\mathrm{NO}_{3}^{-}-\mathrm{N}$ was measured by ion chromatography (ICS-1100), LAS was measured by methylene blue spectrophotometry(UV-1800).

\section{Statistical Analysis}

Data calculation and diagramming were completed by EXCEL 2010. Correlation analysis was carried out by SPSS Statistics 19.0 . 
Table 4. Descriptive statistics of heavy metals during experimental period.

\begin{tabular}{|c|c|c|c|c|c|c|c|}
\hline $\begin{array}{l}\text { Water } \\
\text { source }\end{array}$ & $\begin{array}{l}\text { Heavy } \\
\text { Metal }\end{array}$ & $\begin{array}{l}\text { Max Value } \\
(\mathrm{mg} / \mathrm{kg})\end{array}$ & $\begin{array}{l}\text { Min Value } \\
(\mathrm{mg} / \mathrm{kg})\end{array}$ & $\begin{array}{l}\text { Average } \\
(\mathrm{mg} / \mathrm{kg})\end{array}$ & $\begin{array}{l}\text { Median } \\
(\mathrm{mg} / \mathrm{kg})\end{array}$ & $\begin{array}{l}\text { Standard Deviation } \\
(\mathrm{mg} / \mathrm{kg})\end{array}$ & $\begin{array}{l}\text { Coefficient of } \\
\text { Variation (\%) }\end{array}$ \\
\hline \multirow{5}{*}{ R1 } & $\mathrm{Cd}$ & 0.16 & 0.05 & 0.1 & 0.12 & 0.04 & 37.76 \\
\hline & $\mathrm{Pb}$ & 51 & 32 & 40.67 & 41.5 & 4.87 & 11.98 \\
\hline & $\mathrm{Cr}$ & 39 & 8 & 14.17 & 12.5 & 7.79 & 54.97 \\
\hline & $\mathrm{Cu}$ & 12 & 5 & 8.08 & 8 & 1.75 & 21.7 \\
\hline & $\mathrm{Zn}$ & 60 & 41 & 49.83 & 50 & 5.27 & 10.58 \\
\hline \multirow{5}{*}{$\mathrm{R} 2$} & $\mathrm{Cd}$ & 0.14 & 0.05 & 0.08 & 0.07 & 0.03 & 36.45 \\
\hline & $\mathrm{Pb}$ & 51 & 31 & 43.42 & 45.5 & 7.47 & 17.2 \\
\hline & $\mathrm{Cr}$ & 26 & 13 & 18.25 & 16.5 & 3.92 & 21.47 \\
\hline & $\mathrm{Cu}$ & 8 & 3 & 4.83 & 4.5 & 1.28 & 26.49 \\
\hline & $\mathrm{Zn}$ & 58 & 38 & 49.17 & 49 & 5.15 & 10.46 \\
\hline \multirow{5}{*}{ R3 } & $\mathrm{Cd}$ & 0.14 & 0.07 & 0.1 & 0.1 & 0.02 & 23.36 \\
\hline & $\mathrm{Pb}$ & 64 & 30 & 44.58 & 43 & 10.32 & 23.14 \\
\hline & $\mathrm{Cr}$ & 27 & 17 & 21.08 & 21.5 & 2.33 & 11.03 \\
\hline & $\mathrm{Cu}$ & 10 & 3 & 5.08 & 4 & 2.14 & 42.08 \\
\hline & $\mathrm{Zn}$ & 65 & 40 & 51.58 & 49.5 & 8.18 & 15.86 \\
\hline
\end{tabular}

\section{Results and Discussion}

\section{Pollution Characteristics of Heavy Metals}

According to Zhejiang soil geochemical reference value and environmental background value [25], the pollution characteristic of heavy metals was shown in Table 4. After irrigated with R1, the average value of $\mathrm{Cd}, \mathrm{Pb}, \mathrm{Cr}, \mathrm{Cu}$ and $\mathrm{Zn}$ content in soil was $53.31 \%$, $115.79 \%, 36.26 \%, 44.83 \%$ and $69.09 \%$ compared to the background value. As for R2 irrigation, the averaged content of heavy metals $(\mathrm{Cd}, \mathrm{Pb}, \mathrm{Cr}, \mathrm{Cu}$ and $\mathrm{Zn})$ was $42.99 \%, 123.62 \%, 46.71 \%, 26.81 \%$, 68.16\%, while for R3 irrigation, it was $50.30 \%, 126.95 \%, 53.96 \%, 28.19 \%$, $71.51 \%$, respectively. It illustrated that the heavy metals content in soil was increased after irrigated by reclaimed water. The coefficient of variation reflect the change of heavy metals content. It had a stronger level of variation for $\mathrm{Cd}, \mathrm{Cr}$ and $\mathrm{Cu}(>30 \%)$.

\section{Heavy Metal Dynamics in Soil}

Heavy metal dynamics were shown in Fig. 2. Totally speaking, $\mathrm{Cd}$ and $\mathrm{Pb}$ in soils were increased after rice harvesting compared to the content before rice transplantation, while $\mathrm{Cr}, \mathrm{Cu}$ and $\mathrm{Zn}$ were decreased.

Generally speaking, the $\mathrm{Cd}$ content at top soil layers was obviously higher than that at deep soil. After rice harvesting, the $\mathrm{Cd}$ content with reclaimed water irrigation was highest at $20-40 \mathrm{~cm}$ soil layer under $\mathrm{W} 1$, while it was highest at $0-20 \mathrm{~cm}$ soil layer with R3 irrigation under $\mathrm{W} 1$, and they all highest at $0-20 \mathrm{~cm}$ soil layer under W2 and W3. For Cd content in $0-20 \mathrm{~cm}$ soil layer, it increased obviously under R1 compared to R2 and R3 under different water level regulations. The increasing times after rice harvesting were 2.4, 2 and 1.8 for R1, R2, R3 under W1. They were 3.2, 2 , and 1.6 times under $\mathrm{W} 2$, and also R1 increased greatly at this water level regulation. As for W3, they were $2.8,2.3$ and 1.9 times of the $\mathrm{Cd}$ content before rice transplantation, and it increased most greatly for $\mathrm{R} 2$ and R3. For Cd content in $20-40 \mathrm{~cm}$ soil layer, the increasing rate was highest for R2 under W1 and W2, while it was highest for R1 under W3. The increasing rate at $40-60 \mathrm{~cm}$ and $60-80 \mathrm{~cm}$ soil layers showed the trend of $\mathrm{R} 1>\mathrm{R} 2>\mathrm{R} 3$, which was consistent with the law at $0-20 \mathrm{~cm}$ soil layer. Water resource showed extremely significance on $\mathrm{Cd}$ at $60-80 \mathrm{~cm}$ (Table 5).

Referring to $\mathrm{Pb}$ content at $0-20 \mathrm{~cm}$ soil layer, the increasing rate showed $\mathrm{R} 2>\mathrm{R} 1>\mathrm{R} 3$ under $\mathrm{W} 1$, and it showed $\mathrm{R} 3>\mathrm{R} 2>\mathrm{R} 1$ under $\mathrm{W} 2$, and $\mathrm{R} 1>\mathrm{R} 3>\mathrm{R} 2$ under W3. With higher water level regulation, the increasing rate was higher under R1 irrigation (W3R1 increased $34.4 \%$ ), while it varied small under R2. At $20-40 \mathrm{~cm}$ soil layer, the increasing rate under $\mathrm{W} 1$ and $\mathrm{W} 2$ showed the trend of $\mathrm{R} 1>\mathrm{R} 2>\mathrm{R} 3$, while it was $\mathrm{R} 2>\mathrm{R} 1>\mathrm{R} 3$ under W3. At $40-60 \mathrm{~cm}$, the average increasing rate under R2 was highest, that was $65.9 \%$, while it was lowest under R3, with $0.6 \%$. Therefore, the reclaimed water irrigation increased the $\mathrm{Pb}$ content at $40-60 \mathrm{~cm}$ soil layer obviously, and the increasing rate was highest under W2. At $60-80 \mathrm{~cm}$ soil layer, with $\mathrm{R} 1$ and $\mathrm{R} 2$ irrigation, $\mathrm{Pb}$ content increased $27.6 \%$ and $30.8 \%$ 


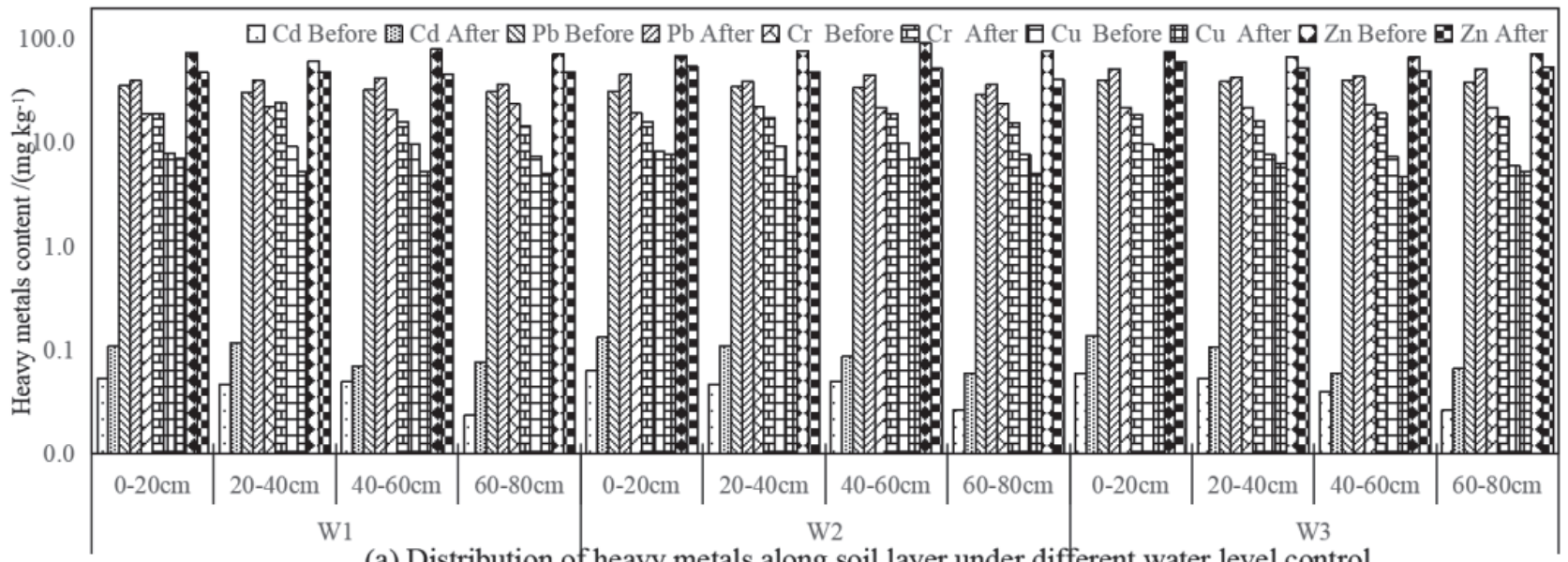

(a) Distribution of heavy metals along soil layer under different water level control

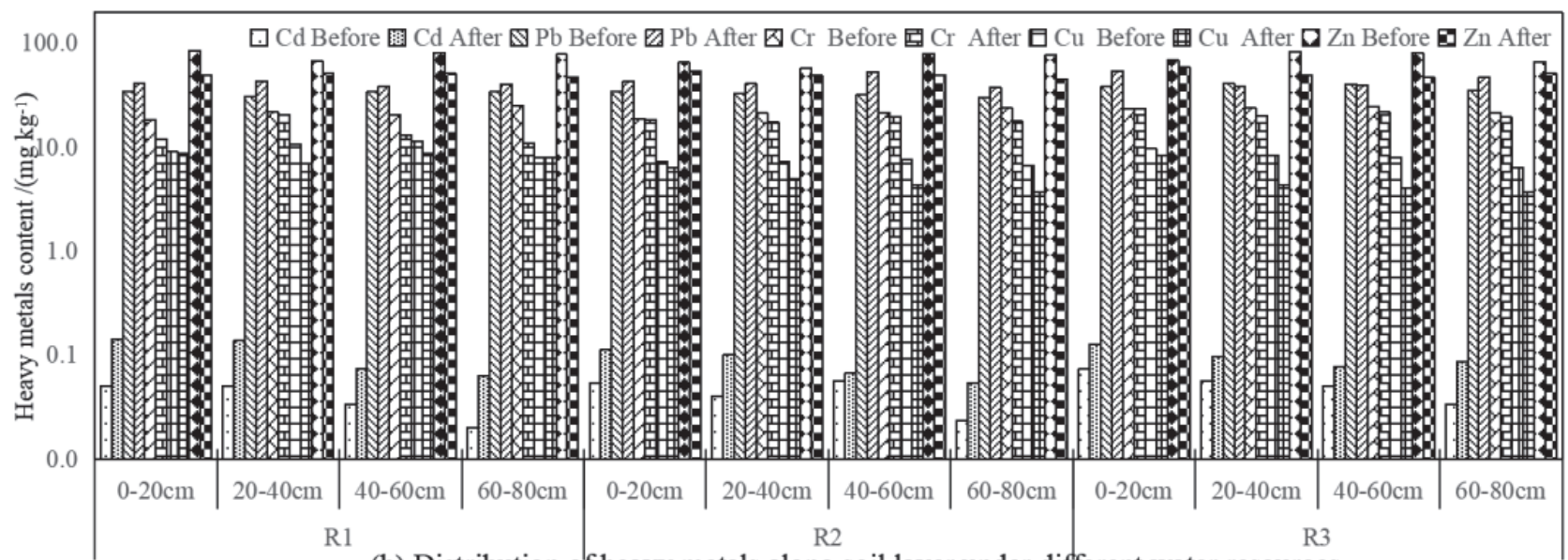

(b) Distribution of heavy metals along soil layer under different water resources

Fig. 2. Heavy metals change before and after growth period of rice.

under W1 regulation, while it did not change with $\mathrm{R} 3$. With the same irrigation water resource, the increasing rate of $\mathrm{Pb}$ was increasing with water level, and they were $19.5 \%, 25.6 \%$, 35.4\% under W1, W2, W3, respectively. Water level regulation effect on $\mathrm{Pb}$ at $60-80 \mathrm{~cm}$ was significant, while other treatment had no difference under different water level and water resources.

As for $\mathrm{Cr}$, most of the treatments were declined except for some under R2 irrigation. The water resource effect was significant on $\mathrm{Cr}$ and $\mathrm{Zn}$ at $0-20 \mathrm{~cm}$ soil layer, and extremely significant on $\mathrm{Cu}$ at $60-80 \mathrm{~cm}$ soil layer, while water level regulation effect on $\mathrm{Zn}$ at $0-20 \mathrm{~cm}$ and $60-80 \mathrm{~cm}$ was extremely significant and significant.

Soil Environmental Quality Standard (GB156181995) showed that, in order to ensure agricultural production and maintain human health, general farmland soil is applicable to the second-level standard. The soil quality basically does not cause harm or pollution to plants and the environment. From the above results, it can be seen that the content of heavy metals in the soil meets the second-level soil environmental quality standard. Therefore, short-term reclaimed

Table 5. Variance analysis on heavy metals in soil layers.

\begin{tabular}{|c|c|c|c|c|c|c|c|c|c|c|}
\hline \multirow{2}{*}{ Soil layer } & \multicolumn{2}{|c|}{$\mathrm{Cd}$} & \multicolumn{2}{|c|}{$\mathrm{Pb}$} & \multicolumn{2}{|c|}{$\mathrm{Cr}$} & \multicolumn{2}{|c|}{$\mathrm{Cu}$} & \multicolumn{2}{|c|}{$\mathrm{Zn}$} \\
\hline & $\mathrm{R}$ & W & $\mathrm{R}$ & W & $\mathrm{R}$ & W & $\mathrm{R}$ & W & $\mathrm{R}$ & W \\
\hline $0-20$ & NS & NS & NS & NS & $*$ & NS & NS & NS & $*$ & $* *$ \\
\hline $20-40$ & NS & NS & NS & NS & NS & NS & NS & NS & NS & NS \\
\hline $40-60$ & NS & NS & NS & NS & NS & NS & NS & NS & NS & NS \\
\hline $60-80$ & $* *$ & NS & NS & $*$ & NS & NS & $* *$ & NS & NS & $*$ \\
\hline
\end{tabular}

Note: ** showed $\mathrm{P}<0.01$, * showed $\mathrm{P}<0.05$, and NS means no significant difference. 
water irrigation will not cause heavy metal pollution to the soil.

\section{Heavy Metals Dynamics in Rice Plant}

The accumulation of heavy metals in different organs of rice plant was shown in Fig. 3. It showed that no $\mathrm{Cu}$ was detected in root, stem, leaf, and grain of rice. As for root part, the average $\mathrm{Zn}$ content under $\mathrm{R} 1$, $\mathrm{R} 2$ and R3 was $11.1 \mathrm{mg} / \mathrm{kg}, 4.2 \mathrm{mg} / \mathrm{kg}, 7.8 \mathrm{mg} / \mathrm{kg}$, and the average $\mathrm{Pb}$ content was $5.33 \mathrm{mg} / \mathrm{kg}, 4.25 \mathrm{mg} / \mathrm{kg}$, $6.84 \mathrm{mg} / \mathrm{kg}$, respectively. The average Cd content was $0.052 \mathrm{mg} / \mathrm{kg}, 0.031 \mathrm{mg} / \mathrm{kg}, 0.131 \mathrm{mg} / \mathrm{kg}$, and the average $\mathrm{Cr}$ content was $2.24 \mathrm{mg} / \mathrm{kg}, 1.76 \mathrm{mg} / \mathrm{kg}, 2.42 \mathrm{mg} / \mathrm{kg}$, respectively. Therefore, the $\mathrm{Zn}$ content under R1 irrigation was increased obviously compared to other irrigation treatments. As for the content of other heavy metals, the change showed the trend of $\mathrm{R} 3>\mathrm{R} 1>\mathrm{R} 2$.

As for the stem part, the average $\mathrm{Zn}$ content under $\mathrm{R} 1, \mathrm{R} 2$ and R3 was $39.9 \mathrm{mg} / \mathrm{kg}, 18.3 \mathrm{mg} / \mathrm{kg}, 13.8 \mathrm{mg} / \mathrm{kg}$, and the average $\mathrm{Pb}$ content was $0.245 \mathrm{mg} / \mathrm{kg}, 0.283 \mathrm{mg} / \mathrm{kg}$, $0.355 \mathrm{mg} / \mathrm{kg}$, respectively. The average $\mathrm{Cd}$ content was $0.041 \mathrm{mg} / \mathrm{kg}, 0.013 \mathrm{mg} / \mathrm{kg}, 0.035 \mathrm{mg} / \mathrm{kg}$, and the average $\mathrm{Cr}$ content was $1.51 \mathrm{mg} / \mathrm{kg}, 1.06 \mathrm{mg} / \mathrm{kg}$, $1.17 \mathrm{mg} / \mathrm{kg}$, respectively. Thus, the $\mathrm{Zn}$ content was significantly increased under reclaimed water irrigation, and it was 2.9 times and 1.3 times for R1 and R2 compared to $\mathrm{R} 3$. The $\mathrm{Pb}$ content was lower under reclaimed water irrigation. The $\mathrm{Cd}$ and $\mathrm{Cr}$ under $\mathrm{R} 1$ was 1.2 times and 1.4 times of that under R3, while it was lower under R2 compared to R3.

As for the leaf part, the average $\mathrm{Zn}$ content under $\mathrm{R} 1, \mathrm{R} 2$ and R3 was $15.3 \mathrm{mg} / \mathrm{kg}, 5.8 \mathrm{mg} / \mathrm{kg}, 11.9 \mathrm{mg} / \mathrm{kg}$, and the average $\mathrm{Pb}$ content was $0.968 \mathrm{mg} / \mathrm{kg}, 0.68 \mathrm{mg} / \mathrm{kg}$, $0.426 \mathrm{mg} / \mathrm{kg}$, respectively. The average $\mathrm{Cd}$ content was $0.02 \mathrm{mg} / \mathrm{kg}, 0.005 \mathrm{mg} / \mathrm{kg}, 0.011 \mathrm{mg} / \mathrm{kg}$, and the average Cr content was $2.89 \mathrm{mg} / \mathrm{kg}, 0.956 \mathrm{mg} / \mathrm{kg}, 1.61 \mathrm{mg} / \mathrm{kg}$, respectively. It showed that the $\mathrm{Zn}, \mathrm{Cd}$ and $\mathrm{Cr}$ content under R1 was $28.6 \%, 81.8 \%$ and $79.5 \%$ higher than that under R3, while it was lower under R2 compared to R3. The $\mathrm{Pb}$ content under $\mathrm{R} 1$ and $\mathrm{R} 2$ was 2.3 times and 1.6 times that under R3.

As for the grain part, the average $\mathrm{Zn}$ content under $\mathrm{R} 1, \mathrm{R} 2$ and R3 was $25.7 \mathrm{mg} / \mathrm{kg}, 23.1 \mathrm{mg} / \mathrm{kg}, 25.4 \mathrm{mg} / \mathrm{kg}$, and the average $\mathrm{Pb}$ content was $0.097 \mathrm{mg} / \mathrm{kg}$, $0.077 \mathrm{mg} / \mathrm{kg}, 0.103 \mathrm{mg} / \mathrm{kg}$, respectively. The average Cd content was $0.01 \mathrm{mg} / \mathrm{kg}, 0.005 \mathrm{mg} / \mathrm{kg}, 0.012 \mathrm{mg} / \mathrm{kg}$, and the average $\mathrm{Cr}$ content was $0.398 \mathrm{mg} / \mathrm{kg}$, $0.568 \mathrm{mg} / \mathrm{kg}, \quad 0.584 \mathrm{mg} / \mathrm{kg}$, respectively. Therefore the heavy metals content under reclaimed water irrigation did not increase obviously, and it could meet the limit requirements for pollutants in rice in the GB 2762-2017 national food safety standard (Table 7). According to significance analysis results, the was no significance among treatments.

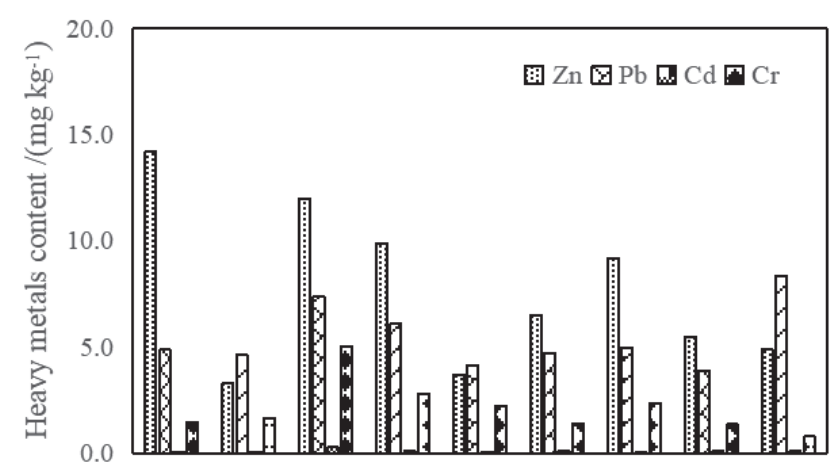

(a) Root

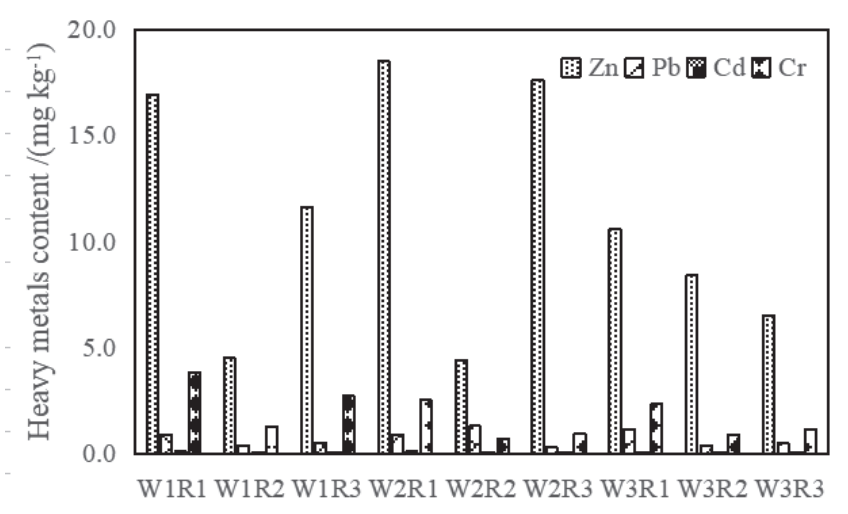

(c) Leaf

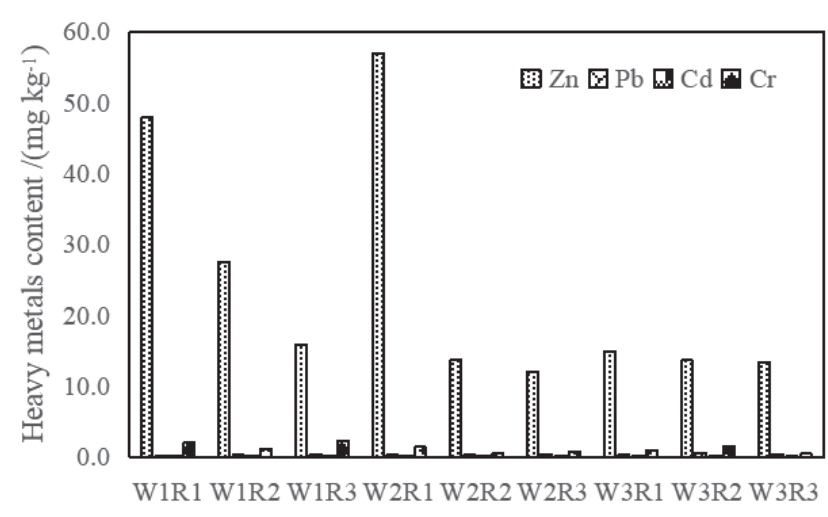

(b) Stem

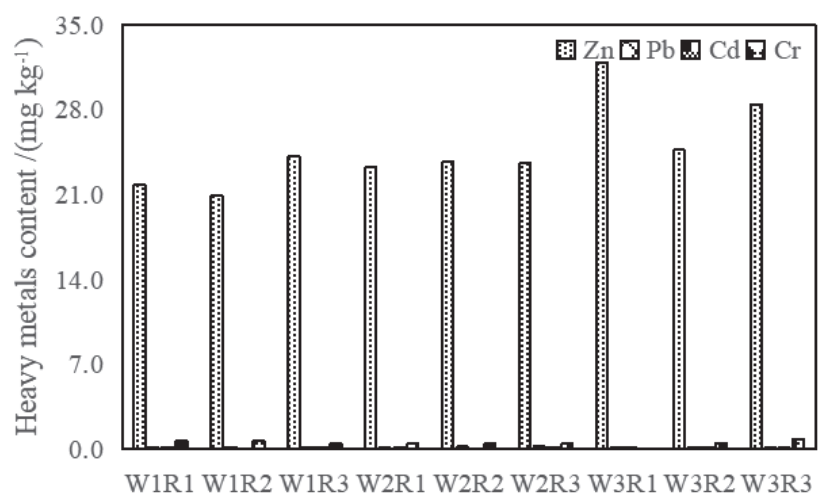

(d) Grain

Fig. 3. Accumulation of heavy metal in rice plant $(\mathrm{mg} / \mathrm{kg})$. 
Table 6. Soil environmental quality standard $(\mathrm{mg} / \mathrm{kg})$.

\begin{tabular}{|c|c|c|c|c|c|}
\hline Levels & First-level & \multicolumn{3}{|c|}{ Second-level } & Third-level \\
\hline Soil $\mathrm{pH}$ & Natural background value & $<6.5$ & $6.5 \sim 7.5$ & $>7.5$ & $>6.5$ \\
\hline Indicator & \multicolumn{5}{|c|}{} \\
\hline $\mathrm{Cd} \leq$ & 0.2 & 0.3 & 0.6 & 1.0 & 500 \\
\hline $\mathrm{Pb} \leq$ & 35 & 250 & 300 & 350 & 400 \\
\hline $\mathrm{Cr} \leq$ & 90 & 250 & 300 & 350 & 400 \\
\hline $\mathrm{Cu} \leq$ & 35 & 50 & 100 & 100 & 500 \\
\hline $\mathrm{Zn} \leq$ & 100 & 200 & 250 & 300 & \\
\hline
\end{tabular}

Table 7. The limit requirements for pollutants in rice grain.

\begin{tabular}{|c|c|c|c|c|c|c|}
\hline Pollutant category & $\mathrm{Cd}$ & $\mathrm{Cr}$ & $\mathrm{Pb}$ & $\mathrm{Hg}$ & $\mathrm{As}$ & $\mathrm{Sn}$ \\
\hline Limit amount $(\mathrm{mg} / \mathrm{kg})$ & 0.2 & 1.0 & 0.2 & 0.02 & 0.2 & 250 \\
\hline
\end{tabular}

Table 8. Potential risk index of heavy metal.

\begin{tabular}{|c|c|c|c|c|c|c|c|c|c|c|c|c|}
\hline \multirow{2}{*}{$\begin{array}{l}\text { Water } \\
\text { source }\end{array}$} & \multirow{2}{*}{$\begin{array}{l}\text { Soil depth } \\
\text { (cm) }\end{array}$} & \multicolumn{2}{|c|}{$\mathrm{Cd}$} & \multicolumn{2}{|c|}{$\mathrm{Pb}$} & \multicolumn{2}{|c|}{$\mathrm{Cr}$} & \multicolumn{2}{|c|}{$\mathrm{Cu}$} & \multicolumn{2}{|c|}{$\mathrm{Zn}$} & \multirow{2}{*}{ RI } \\
\hline & & $P_{i}$ & $\mathrm{E}_{\mathrm{i}}$ & $P_{i}$ & $E_{i}$ & $\mathrm{P}_{\mathrm{i}}$ & $\mathrm{E}_{\mathrm{i}}$ & $P_{i}$ & $\mathrm{E}_{\mathrm{i}}$ & $P_{i}$ & $E_{i}$ & \\
\hline \multirow{4}{*}{$\mathrm{R} 1$} & $0-20$ & 2.80 & 84.00 & 1.18 & 5.90 & 0.65 & 1.31 & 0.93 & 4.63 & 0.59 & 0.59 & 96.43 \\
\hline & $20-40$ & 2.73 & 82.00 & 1.44 & 7.20 & 0.63 & 1.27 & 0.81 & 4.04 & 0.78 & 0.78 & 95.28 \\
\hline & $40-60$ & 2.25 & 67.50 & 1.13 & 5.66 & 0.64 & 1.28 & 0.81 & 4.05 & 0.65 & 0.65 & 79.14 \\
\hline & $60-80$ & 3.17 & 95.00 & 1.18 & 5.90 & 0.44 & 0.88 & 1.04 & 5.19 & 0.61 & 0.61 & 107.57 \\
\hline \multirow{4}{*}{$\mathrm{R} 2$} & $0-20$ & 2.11 & 63.33 & 1.23 & 6.17 & 1.00 & 2.01 & 0.86 & 4.29 & 0.84 & 0.84 & 76.63 \\
\hline & $20-40$ & 3.00 & 90.00 & 1.25 & 6.23 & 0.81 & 1.62 & 0.69 & 3.45 & 0.85 & 0.85 & 102.16 \\
\hline & $40-60$ & 1.18 & 35.33 & 1.66 & 8.30 & 0.92 & 1.84 & 0.57 & 2.86 & 0.64 & 0.64 & 48.96 \\
\hline & $60-80$ & 2.39 & 71.67 & 1.27 & 6.35 & 0.77 & 1.53 & 0.56 & 2.78 & 0.61 & 0.61 & 82.93 \\
\hline \multirow{4}{*}{ R3 } & $0-20$ & 1.75 & 52.46 & 1.50 & 7.52 & 0.96 & 1.91 & 0.87 & 4.33 & 0.87 & 0.87 & 67.09 \\
\hline & $20-40$ & 1.74 & 52.33 & 0.94 & 4.69 & 0.85 & 1.69 & 0.51 & 2.57 & 0.62 & 0.62 & 61.91 \\
\hline & $40-60$ & 1.53 & 46.00 & 0.99 & 4.97 & 0.88 & 1.77 & 0.51 & 2.55 & 0.61 & 0.61 & 55.89 \\
\hline & $60-80$ & 2.69 & 80.83 & 1.36 & 6.78 & 0.91 & 1.81 & 0.59 & 2.94 & 0.79 & 0.79 & 93.15 \\
\hline
\end{tabular}

\section{Soil Environmental Risk Analysis under Reclaimed Water Irrigation}

Heavy metals are not easy to leaching out with water in the soil, nor can they be decomposed by microorganisms. They are easy to accumulate in the soil, accumulate in the human body through the food chain, and seriously endanger human health. In this study, the potential ecological risk index evaluation method proposed by Hakanson was used to analyze the potential ecological risk of heavy metals in the soil of the farmland irrigated by different water sources in the study area[26]. The formula is as follows.

$$
R I=\sum E_{\mathrm{i}}=\sum T_{i} \times P_{i}
$$

Which, RI was comprehensive potential ecological risk index of multiple heavy metals in soil; $E_{i}$ was ecological risk coefficient of single factor of each evaluation index in soil samples; $\mathrm{P}_{\mathrm{i}}$ was pollution index of single factor, which is the ratio of the measured value of a single pollution factor to the corresponding background value; $T_{i}$ was toxicity coefficient of heavy metals in soil, and the Ti value showed the trend of $\mathrm{Zn}$ $(1)<\mathrm{Cr}(2)<\mathrm{Cu}<\mathrm{Pb}(5)<\mathrm{Cd}(30)$.

The comprehensive potential risk index of heavy metals in different soil layers under different water source irrigation conditions was shown in Table 10. 
Table 9. Ecological risk rating standard of heavy metal.

\begin{tabular}{|c|c|c|c|c|}
\hline \multirow{2}{*}{ Degree } & \multicolumn{2}{|c|}{ Ecological risk of single factor } & \multicolumn{2}{c|}{ Total potential ecological risk } \\
\cline { 2 - 5 } & Ei & Ecological risk degree & RI & Ecological risk degree \\
\hline I & $<40$ & Mild & $<150$ & Mild \\
\hline II & $40 \sim 80$ & Moderate & $150 \sim 300$ & Moderate \\
\hline III & $80 \sim 160$ & Stronger & $300 \sim 600$ & Stronger \\
\hline IV & $160 \sim 320$ & Very strong & $>600$ & Very strong \\
\hline V & $>320$ & Extremely strong & & \\
\hline
\end{tabular}

The ecological risk coefficient of $\mathrm{Cd}$ in the soil was the highest, followed by $\mathrm{Cu}$ and $\mathrm{Pb}$, and the risk coefficient of $\mathrm{Cr}$ and $\mathrm{Zn}$ was lower. Referring to the risk rating standard (Table 9), it can be seen that the reclaimed water irrigation did not cause serious pollution to the soil, and the ecological risk was mild. Among them, the soil risk index at $60-80 \mathrm{~cm}$ soil layer was the highest under R1 irrigation, while it was the highest at $20-40 \mathrm{~cm}$ soil layer under R2. It can be seen that heavy metals can penetrate the soil and pollute groundwater under R1. Among them, the ecological risk of $\mathrm{Cd}$ under irrigation of various water sources was the highest. R1 was at a strong risk on average, and R2 and R3 were at moderate risks. Therefore, compared with river water irrigation, the potential ecological risk of heavy metal pollution in the soil under R2 irrigation did not increase. And the risk of groundwater pollution was also small.

\section{Correlation between High-Risk Heavy Metals and Soil Properties}

The correlation between soil heavy metal content and soil chemical properties under different water source was shown in Table 10. Generally speaking, under reclaimed water irrigation, $\mathrm{Cd}$ had extremely significant correlation to soil Ec, while it had significant correlation to $\mathrm{pH}$ and sanity. $\mathrm{pH}$ only had significant correlation to $\mathrm{Cd}$ compared to other heavy metals under $\mathrm{R} 1 . \mathrm{Pb}$ had extremely significant correlation to Ec and sanity under R1 irrigation water source and had significant correlation to Ec, sanity, $\mathrm{NH}_{4}^{+}-\mathrm{N}, \mathrm{NO}_{3}^{-}-\mathrm{N}$ under R2. Cr had significant correlation to Ec and sanity under R1 and R2. Cu had extremely significant correlation to $\mathrm{NH}_{4}^{+}-\mathrm{N}$ under $\mathrm{R} 2$. $\mathrm{Zn}$ had significant correlation to sanity and $\mathrm{NH}_{4}^{+}-\mathrm{N}$. As for R3,

Table 10. Correlation between heavy metal content and soil factors of heavy metals.

\begin{tabular}{|c|c|c|c|c|c|c|c|}
\hline Water source & Heavy metal & $\mathrm{pH}$ & $\mathrm{Ec}$ & $\begin{array}{c}\text { Organic } \\
\text { matter }\end{array}$ & Sanity & $\mathrm{NH}_{4}^{+}-\mathrm{N}$ & $\mathrm{NO}_{3}{ }^{-}-\mathrm{N}$ \\
\hline \multirow{5}{*}{ R1 } & $\mathrm{Cd}$ & $-0.336^{*}$ & $0.971 * *$ & $0.435^{*}$ & $-0.575^{*}$ & -0.109 & $0.369^{*}$ \\
\hline & $\mathrm{Pb}$ & 0.156 & $0.816^{* *}$ & 0.259 & $-0.827 * *$ & -0.209 & $0.342 *$ \\
\hline & $\mathrm{Cr}$ & -0.115 & $-0.765^{*}$ & $-0.567 *$ & $0.780 *$ & -0.034 & -0.081 \\
\hline & $\mathrm{Cu}$ & -0.242 & $-0.563^{*}$ & -0.041 & $0.791 *$ & 0.232 & $-0.739 *$ \\
\hline & $\mathrm{Zn}$ & -0.286 & $-0.714^{*}$ & $-0.513 *$ & $0.681^{*}$ & $0.373 *$ & -0.168 \\
\hline \multirow{5}{*}{$\mathrm{R} 2$} & $\mathrm{Cd}$ & $-0.635^{*}$ & $0.934 * *$ & 0.125 & $0.842 * *$ & $-0.584 *$ & 0.045 \\
\hline & $\mathrm{Pb}$ & -0.084 & $0.400 *$ & -0.262 & $-0.532 *$ & $-0.591 *$ & $-0.318^{*}$ \\
\hline & $\mathrm{Cr}$ & $0.426^{*}$ & $-0.619 *$ & -0.236 & $0.519 *$ & $0.494 *$ & -0.062 \\
\hline & $\mathrm{Cu}$ & $-0.423 *$ & -0.051 & $0.437 *$ & 0.289 & $0.800 * *$ & $0.677^{*}$ \\
\hline & $\mathrm{Zn}$ & 0.056 & -0.262 & 0.186 & $0.615^{*}$ & $0.685^{*}$ & 0.145 \\
\hline \multirow{5}{*}{$\mathrm{R} 3$} & $\mathrm{Cd}$ & $-0.330^{*}$ & 0.018 & $0.651 *$ & $0.699 *$ & -0.284 & $0.601 *$ \\
\hline & $\mathrm{Pb}$ & -0.235 & 0.040 & $0.684 *$ & $0.590^{*}$ & -0.201 & $0.359^{*}$ \\
\hline & $\mathrm{Cr}$ & $-0.596^{*}$ & -0.133 & $0.347 *$ & -0.066 & 0.179 & -0.222 \\
\hline & $\mathrm{Cu}$ & $-0.842 * *$ & -0.153 & $0.508^{*}$ & $0.358^{*}$ & $0.458^{*}$ & 0.191 \\
\hline & $\mathrm{Zn}$ & $-0.446^{*}$ & -0.019 & 0.012 & -0.234 & $0.332 *$ & -0.273 \\
\hline
\end{tabular}

Note: ** showed extremely significant correlation, * showed significant correlation. 
only $\mathrm{Cu}$ had extremely significant correlation to $\mathrm{pH}$, and all heavy metal content had no significant correlation to Ec. Therefore, with reclaimed water irrigation, the change of heavy metals content was mainly related to soil Ec. The $\mathrm{Cd}, \mathrm{Pb}$ was positive correlated to Ec, while $\mathrm{Cr}, \mathrm{Cu}$ and $\mathrm{Zn}$ was negative correlated to Ec. $\mathrm{NH}_{4}^{+}-\mathrm{N}$ only had significant effect to heavy metals under R2. Therefore, Ec and sanity of soil could affect the heavy metal content obviously with reclaimed water irrigation.

\section{Limitation}

In this study, the reclaimed water irrigation experiment was only conducted for one year, and the accumulation of heavy metals in the soil was not obvious in the short time according to the results obtained above, and also the content of heavy metals in the soil and crop grains is far below the allowable value specified by the national standard. Therefore short-term irrigation of reclaimed water will not cause pollution to the soil environment and crops. Meantime, there is no significant difference in the content of heavy metals in the soil under different reclaimed water irrigation. The results were consistent with other researcher's [27]. However, the results obtained are only short-term effects. Whether long-term secondary reclaimed water irrigation will increase the risk of heavy metal pollution remains to be studied in the future.

\section{Conclusions}

1. The Cd content at different soil layers increased greatly with R1 irrigation, and it increased obviously at the surface soil with higher water levels control, while it was opposite at deep soil, showing the trend of increasing obviously with lower water level regulation. With higher water level regulation, the increasing rate of $\mathrm{Pb}$ content at topsoil $(0-20 \mathrm{~cm})$ was higher under R1 irrigation. Under reclaimed water irrigation, $\mathrm{Pb}$ content at 40-60 $\mathrm{cm}$ soil layer increased obviously.

2. $\mathrm{Zn}$ content in root, stem, leaf and grain of rice plant under R1 irrigation was increased obviously compared to other irrigation treatments, while $\mathrm{Pb}$ and $\mathrm{Cr}$ content in root, stem and grain was higher under R3 irrigation. However, $\mathrm{Pb}, \mathrm{Cd}$ and $\mathrm{Cr}$ in leaf was higher under R1 and R2. Cd content in root and stem showed opposite change trend under R1 and R2, while $\mathrm{Cd}$ in grain was higher under R3.

3. Though the soil heavy mental content increased with vary degrees under reclaimed water irrigation, the soil quality basically does not cause harm or pollution to plants and the environment. And also the heavy metals content under reclaimed water irrigation could meet the limit requirements for pollutants in rice in national food safety standard.

\section{Acknowledgments}

This research was funded by National Key Research and Development Program (2019YFC0408803), Basic Public Welfare Research Project of Zhejiang Province (LGN20E090001), Major scientific and technological projects of Zhejiang Provincial Department of water resources (RA1913), Water conservancy science and technology in Zhejiang Province (RC1918, RC2029), National Natural Science Foundation of China (52009044). We also fully appreciate the editors and all anonymous reviewers for their constructive comments on the manuscript.

\section{Conflict of Interest}

The authors declare no conflict of interest.

\section{References}

1. WANG S.Y., WU W.Y., LIU F., ZHAO M., QIU J.Q., WU J.J. Assessment of human health risks of heavy metals in the typical sewage irrigation areas. China Environmental Science, 38, 1550, 2018.

2. ZHOU Y., LI P., QI X.B., HU C., GUO W. Influence of nitrogen rate on nitrogen release pattern in soil irrigated with reclaimed wastewater. Acta Scientiae Circumstantiae, 36, 1369, 2016.

3. JING R., CUI E., FAN X., HU C., LI Z.Y., ZHAO Z., LI S.J., LIU Y. Effects of different potassium (K) fertilizers on cadmium content in soil-crop system under reclaimed water irrigation. Journal of Soil and Water Conservation, 33, 328, 2019.

4. WANG Z., LI J.S., LI Y.F. Using reclaimed water for agricultural and landscape irrigation in China: a review. Irrigation and Drainage, 66, 672, 2017.

5. CUI B.J., GAO F., HU C. The use of brackish and reclaimed waste water in agriculture: A review. Irrigation and Drainage, 38, 60, 2019.

6. GUO W.J., CHEN L., LI L.D., TANG X.Q. Present situation and countermeasures of domestic sewage treatment in rural area - a case study on Yongkang city of Zhejiang province. China Water Resource, 2, 68, 2020.

7. NJUGUNA S.M., MAKOKHA V.A., YAN X., GITUTU R.W., WANG Q.F., WANG J. Health risk assessment by consumption of vegetables irrigated with reclaimed waste water: A case study in Thika (Kenya). Environmental Management, 231, 576, 2019.

8. ZALACAIN D., MARTINEZ-PEREZ S., BIENES R., GARCIA-DIAZ A., SASTRE-MERLIN A. Salt accumulation in soils and plants under reclaimed water irrigation in urban parks of Madrid (Spain). Agricultural Water Management, 213, 468, 2019.

9. EREL R., EPPEL A., YERMIYAHU U., BEN-GAL A., LEVY G., ZIPORI I., SCHAUMANN G.E., MAYER O., DAG A. Long-term irrigation with reclaimed wastewater: Implications on nutrient management, soil chemistry and olive (Olea europaea L.) performance. Agricultural Water Management, 213, 324, 2019. 
10. LI Y.F., LI J.S., ZHAO W.X., WANG Z. Review on irrigation technology applying sewage effluent - advances and prospects. Agricultural Machinery, 46, 102, 2015.

11. GUO W., QI X.B., LI Z.Y., LI P. Impact of reclaimed water on soil microenvironment under different nitrogen levels. Journal of Soil and Water Conservation, 29, 311, 2015.

12. XU X., SUN W., WU W., LIU H., LI F., DOU C. Effect of irrigation with reclaimed water on soil salt and ion content in Beijing. Translation of the CSAE, 26, 34, 2010.

13. LIU Y.P., LIU H.Y., WU L.H., XU M., CUI J.L., GAO W.Y., CHEN C., YUE X.H. Co-contamination of heavy metals and antibiotics in soils under husbandry wastewater irrigation in Guiyang City. Acta Scientiae Circumstantiae, 37, 1074, 2017.

14. YANG J., CHEN T.B., LEI M., LIU H.L., WU W.Y., ZHOU J. Assessing the effect of irrigation with reclaimed water: the soil and crop pollution risk of heavy metals. Journan of Natural Resources, 26, 2097, 2011.

15. ANGIN I., YAGANOLU A.V., TURAN M. Effects of long-term wastewater irrigation on soil properties. Journal of Sustainable Agriculture, 26, 31, 2005.

16. ZHAO Z.M., CHEN W.P., JIAO W.T., WANG M.E. Effect of reclaimed water irrigation on soil properties and vertical distribution of heavy metal. Environmental Science, 33, 4094, 2012.

17. HAN Y., QIAO D., QI X. Effects of reclaimed water irrigation levels on soil salinity and composition of soil bacteria community. Translation of the CSAE, 36, 106, 2020.

18. HU Y.Q., WU W.Y., XU D., LIU H.L. Impact of long-term reclaimed water irrigation on trace elements contents in agricultural soils in Beijing, China. Water, 10, 1716, 2018.

19. BAO Z., WU W.Y., LIU H.L., CHEN H.H., YIN S.Y. Impact of long-term irrigation with sewage on heavy metals in soils, crops, and groundwater - a case study in Beijing. Polish Journal of Environmental Studies, 23, 309, 2014.

20. LU S., WANG J., PEI L. Study on the effects of irrigation with reclaimed water on the content and distribution of heavy metals in soil. Environmental Reearch and Public Health, 13, 298, 2016.

21. LIU C.Z., WANG Y.H., ZHAO J. Assessment of cadmium accumulation in rice and risk on human health in Northeast Sichuan. Geology in China, http://kns.cnki.net/kcms/detail /11.1167.P.20200507.1216.002.html, 2020.

22. WANG R., DENG H., JIA Z.M. Characteristics of cadmium enrichment and pollution evaluation of a soilcrop system in a typical karst area. Environmental Science, 42, 941, 2021.

23. SHAN Z.Q., SHI S.M., MA R.K., YANG X.L. Soil heavy metals pollution and ecological risk assessment in citrus production areas of Guigang, Guangxi Province. Sichuan Environment, 39, 136, 2020.

24. DOU W.Q., AN Y., QIN L., LIN D.S., DONG M.M. Characteristics of vertical distribution and migration of heavy metals in farmland soils and ecological risk assessment. Environmental Engineering, 39, 166, 2021.

25. WANG Q.H., DONG Y.X., ZHENG W., ZHOU G.H. Zhejiang soil geochemical reference value and environmental background value. Geological Bulletin of China, 23, 81, 2007.

26. HAKANSON L. An ecological risk index for aquatic pollution control a sediment to logical approach. Water Research, 14, 975, 1980.

27. WU C.L., HUANG G.H., LIU H.L., WU W.Y., XU C.P. Experimental investigation on heavy metal distribution in soil-crop system with irrigation of treated sewage effluent. Translation of the CSAE, 22, 91, 2006. 
